\title{
Islam and government: an analytical review on Khumayni's Kashf al-Asrār and Wilāyat al-Fāqih
}

\author{
Sudarnoto Abdul Hakim \\ State Islamic University (UIN) Syarif Hidayatullah Jakarta \\ E-mail: sudarnoto.hakim@gmail.com \\ DOI: $10.18326 /$ ijims.v8i1.147-171
}

\begin{abstract}
This paper is an attempt to scrutinize Khumayni's ideas especially on government as explained in his works Kashf al-Asrär, and Wilàyat al-Fäqih. While focusing on Khumayni's ideas as the main issues of discussion, the paper tries to find the significance of the ideas for the Iranian revolution in 1979.The paper argues that the ideas on government were mainly triggered by the Reza Shah's dictatorial, and secular government. It is not exaggerated to mention that according to Khumayni a new sytem of government based on Islamic ideology as a revolutionary system of government was needed in a sense that an Islamic government will implement justice. As will be discussed later, the idea of Islamic government as the single alternative was extensively supported by students, intelligentsias, urban peoples, poor peoples, and others.
\end{abstract}

Artikel ini berusaha mendiskusikan pemikiran Imam Khumayni tentang pemerintah sebagaimana yang dijelaskan dalam karyanya Kasyf al-Asrar dan Wilayat Faqih. Sambil memberikan perhatian terhadap isu pokok, artikel ini ingin menggali kaitan kuat pemikiran Khumayni dengan revolusi Iran yang terjadi pada tahun 1979. Penulis berpandangan bahwa gagasan-gagasannya tentang pemerintah merupakan respons atau sikapnya terhadap kecenderungan pemerintahan diktatorial dan sekular Reza Shah. Tidak berlebihan untuk dinyatakan bahwa menurut Imam Khumayni sebuah pemerintahan 
Revolusioner yang didasarkan kepada Ideologi Islam sangat dibutuhkan karena pemerintahan Islam seperti inilah yang akan mampu menegakkan keadilan. Sebagaimana yang akan didiskusikan nanti ide pembentukan pemerintah ini memperoleh dukungan secara ekstensif antara lain dari mahasiswa, inteligensia, masyarakat kota dan orang-orang miskin.

Keywords: Kashf al-Asrār; Wilāyat al-Fäquih, Shi'ism; Iranian Islamic revolution; Imamate

\section{Introduction}

Under the western imperialist's strong influence and subordination modernization in Iran was imposed. The Shah's regime adopted European style-modernization by implementing capitalism, importing, and promoting western culture, and its corollary of vulgarized western values, and morals. Even, the regime marginalized the roles of Islam and Mujtahid as well by secularizing, and establishing a system of secular court. The weakness of the roles of Ulama could be clearly seen from their position in the Majelis. Consequently, the laws enforced during the Reza Khan's regime had not been vetted by Mujtahid and the government then became more authoritarian, and even dictatorial. The laws enforced were contradictory with the demands of justice, and religion. It is not exaggerated to underline that the western style-modernization as imposed by the Reza Khan's regime caused political repression, economic exploitation, cultural alienation, and moral corruption.

The situation resulted in the public dissatisfaction, and mass opposition from the great Ulama, students, intelligentsias, urban middle class society, and others. They did not merely criticized the regime but also demanded radical change. They propogated a new system of government based on Islamic ideology as the only one alternative for the sake of prosperity, justiceand peace. Khumayni, among the others, was one of the 
greatest, and very influencial Ulama who propogated and stimulated a revolutionary movement to both abolish the secular dictatorial regime of Shah and establish an Islamic government as well. Khumayni exposed clearly his arguments to establish such Islamic government through his works Kashf al-Asrār, and Wilāyat al-Fäqih. These two books were written in a different timeand situasion but the same spirit to change the system of government from the secular and authoritarian ones into Islamic, and democratic namely Islamic Republic of Iran. Being intellectually influenced by many greatest Ulama of Iran such as Ayatullah Abd al-Karim Ha'iri, the power of revolutionary ideas of Khumayni as exposed in Kashf al-Asrär, and Wilayat al-Fäqih was undoubtadly enlighthening the peoples included students, intelligentsias, and urban middle class of Iran and stimulating them to oppose, and abolish the Shah's regime and establish the Islamic government. It means that the correlation between the intellectual notions of Khumayni as expressed in these two book, and the political situation in Iran was very clear. Khumayni's notions were very fundamental in the context of modern history of Iran in a sense that western style-modernization, secularism, and authoritarianism could not work at all since it undermined the Iranian local wisdom, tradition, worldview, and ideology.

I explored Khumayni's works as compiled and translated in English by Hamid Algar in Islam and Revolution. ${ }^{1}$ I referred to this book to start understanding Khumayni's ideas, and his significant contribution to the implementation of a new or alternative ideological principles of Islamic government. Sa'id Najafiyan's serial articles published in a journal alTawhid ${ }^{2}$ were also very important sources of my article. I did not merely

\footnotetext{
${ }^{1}$ Khomeini, Islam and Revolution, trans. Hamid Algar, Berkeley: Mizan Press, 1981.

2 Sa'id Najafiyan, "Imam Khumayni: Life and Works," al-Tawhid, vol. VII, no. 4 (MayJune 1990), 117-135 and vol.VIII no 2 (November 1990-January 1991), 137-150
} 
find Khumayni's life journey from this journal but also his works. I tried to put Khumayni's ideas in the context of Iranian political dyanamics particularly to analyze the trend of Islamic Revolution as, then we see, controlled by Khumayni. So, I referred some academic works like written by Shaul Bakhash, Jamahir Amuzegar, Dilip Hiro, Cheryl Bernard and Zalman Khalizad, S. Akhavi, Haleh Afshar and Said Arjomand. These sources are absolutely meaningful, and helpful for me to underst and the essence of the idea of Islamic government, to analyze the reasons, and arguments behind the idea. and to connect the idea with the political reality and dynamics of Iran as well.

The paper starts by discribing Khumayni's life journey which consist of his family background, and intellectual interests and experiences. The following part of the paper is an attempt to examine the impact of modernization which was followed by secularization and westernization. The public dissatisfaction, and misseries caused by Shas's dictatorial regime and criticism or condemnation from the Shi' ite Ulama had strongly stimulated an Islamic Revolution. This issue is also discussed. Another part of the paper will scrutinize Khumayni's ideas in his Kashf al-Asrär and Wilayat al-Fäqih followed by the idea of necessity of the Islamic government, and lastly pays attention to Khumayni's opinion on Fiqh.

\section{Biographical sketch}

His name is al-Musavi al-Khumayni then famed as Imam Ruhullah al-Musavi al-Khumayni. He was born on September 14th,1902 in Khumayn, a small town hundred kilometers to the South-West of Tehran. His father was Sayyid Musthofa, a well known and beloved scholar at that time. He was killed by agents of Reza Khan, the father of Shah, only five months after the birth of Khumayni. His great grandfather, Sayyid alDin Ali Shah, a religious scholar from Nashapur, is said to have attained 
martydom. He migrated to Kashmir, where he settled down. His son, Sayyid Ahmad, known as Sayyid Ahmad Hindi, undertook a journey to the holy city of Karbala, and Najaf in Iraq for religious studies. ${ }^{3}$ Najafiyan points out that he travelled to Khumayn with the purpose of making it his home. Sayyid Ahmad married Sukaynah Khanum and they got three daughters, and a son, Sayyid Mustafa. Sayyid Mustafa, Khumayni's father, ${ }^{4}$ became a popular, and influential figure as he dedicated him self to protect the defenceless from the tyrany and oppression of the local feudal lords. Najafiyan underlines that during the tyrannical rule of the Qajjar, Sayyid Mustafa valiantly resisted the local predatory Khan and feudal hoodlums who preyed upon the defenceless and weak people.

Khumayni's early education was under responsible of his mother, aunt and elder brother, Sayyid Murtadha. ${ }^{5}$ But when they were away in Tehran, where they had rented a house and stayed for the sake of justice from the Qajjar court, he had been left in the care of his nurse, Naneh Khawar. He started his education at Khumayn in the Maktab Khaneh of Akhund Mulla Abu Qasim, an old man whose Maktab Khaneh was close to his home. ${ }^{6}$ After finishing his study on Qur'an in the Maktab ${ }^{7}$ Khumayni then continued his study in Arabic under both his paternal cousin, Syaikh Ja'far, and maternal uncle, Mirza Mahmud. At that time Khumayni studied Jami' Muqaddimat, a common text book of Arabic Grammarand Logic (al-Mantiq). There were other Khumayni's teachers

\footnotetext{
${ }^{3}$ Sa'id Najafiyan, "Imam Khumayni..., 118.

${ }^{4}$ Sa’id Najafiyan, "Imam Khumayni..., 118.

${ }^{5}$ Sayyid Murtadha was better known in later years as Ayatullah Pasandideh or Ayatullah Morteza Pasandideh. He, who was born on April 1, 1896 in Khomein, studied Literature, Logic, Theology, and (Ptolemaic) Astronomy in Isfahan. He acquired the equivalent of a doctorate in Theology. Pasandideh became Imam of a mosqueand established a school of theology to train Mullahs. Many argue that politically Pasandideh was more liberal than Imam Khumayni.

${ }^{6}$ Sa'id Najafiyan, "Imam Khumayni..., 119.

${ }^{7}$ At that time he was seven years old.
} 
on Arabic and Logic i.e.Hajj Mirza Ridha Najafi, his sister's husband, his elder brother Sayyid Murtadha. Sayyid Murtadha also tought him two important text books on Arabic Grammar, and Syntax (Mutawwal,and Suyuti). Khumayni was also intersted in studying Caligraphy (Khat-e Nasta'liq).

In 1920, when Khumayni was nineteen years old, he was proceeded continuing his study to Arak. He studied Logic under Syaikh Muhammad Gulpayagni and Sharhe Lum'ah under supervision of Aqa' Abbas Araki. During 1920s he met great and distinguished scholars, and became their student. Some of them was Ayatullah Syaikh Abd al-Karim Ha'iri, the founder of theological school of Qumm. Ha'iri was a leading scholar of Arak. Accordingly, when Ha'iri left Arak for Qumm in 1922 Khumayni followed him, and became his student. Khumayni was a brilliant student, and excelled other Ha'iri's students in a wide variety of subjects, especially Ethics, and Irfan (spiritual philosophy). He also attended Ha'iri's advanced lectures (Dars-e Kharji) on Fiqh and Usül al-Fiqh during the years 1926-1936. ${ }^{8}$ Undoubtedly, under supervision of Ha'iri Khumayni was an heir to the tradition established by the influential figures of the 19th century Iran. During these years Khumayni wrote a treatise in Arabic on Ethics, and Irfan entiteled Mișbăh al-Hidāyah. ${ }^{9}$ Undoubtedly, the influence of Ha'iri's thought on Khumayni's spiritual philosophy was very strong. This treatise was well received by his teacher ${ }^{10}$ symbolizing Ha'iri's acknowledgment of Khumayni's intellectual work. When Ha'iri passed away in 1937 Khumayni was not merely known as one of the leading scholars, and scholastic genious as well but, as Hamid Algar points out, was also very active in promoting the candidacy of Ayatullah

\footnotetext{
${ }^{8}$ Sa'id Najafiyan, "Imam Khumayni..., 121.

${ }^{9}$ Khumayni was twenty years old at that time.

${ }^{10}$ Khumayni, Islam and Revolution..., 14.
} 
Islam and government: an analytical review on Khumayni's ... (Sudarnoto Abdul Hakim)

Hajj Aqa Husayn Burujerdi (1875-1960) as successor of Ha'iri's position. Khumayni expected Burujerdi ${ }^{11}$ to utilize the wide influences and potentialities of the position of supreme religious authority (Marja'iyah) in order to combat Pahlavi's power. ${ }^{12}$

Khumayni was also strongly influenced by Ayatullah Muhammad Ali Shahabadi (1875-1953). He was recognized as the great philosopher, prolific writer, and staunch opponent of the dictatorial regime of Reza Khan. Khumayni met Ayatullah Shahabadi one day in the Madraseh Faydiyah and asked him about Irfan or spiritual philosophy. He studied Tasawuf from him Sharh al-Fusus al-Hikam. This books is Qaysari's exposition of Ibn Arabi's ${ }^{13}$ mystical work Fușus al-Hikam (The Seal of Wisdom). ${ }^{14}$ Then he also studied another mystical works such as Mafätị al-Ghaib and Manāzil al-Sairin's Kwajjah Abd Allah Ansari. ${ }^{15}$ His interest in text books on philosophy was also strong. Some of the text books on philosophy were Sabzawari's Manzumah and Mulla Sadra's Asfar. In addition, he also attended lectures given by some other great ulama or scholars in various subjects of Islam. Some of them were Ayatullah Hajj Mirza Jawad Maliki

${ }^{11}$ Khumayni attended Borujerdi's lectures by 1945 when he came to Qumm.

${ }^{12}$ Khumayni, Islam and Revolution..., 15.

${ }^{13}$ Born on July $26^{\text {th }}, 1165$, Ibn Arabi was a wellknown, and controversial scholar who pioneered the idea of al-Wihdat al-Wujud or al-Ittihad. Many orthodox Ulama rejected the al-Wihdat al-Wujud because it was considerably very speculative, and heretic. Some argue that Ibn Arobi wrote some 800 works although only some have been authenticated. Recent research mentions that more than 100 of Arabi's works have survived in manuscript form. But most printed versions have not yet been edited.

${ }^{14}$ Some argue that there are more than fifty commentaries on the Fusus. An English translation of his own summary of the Fusus, Naqsh al-Fusus (the Imprint of Pattern of the Fusus) as well as commentary on this work by Abd al-Rahman Jami, Naqd al-Nusus fi Sharh\} al-Fusus done by William Chittik. It was published in the Journal of the Muhyiddin Ibn Arabi Society, volume 1. Additionally, the first full English translation of this book was done by Ralph Austin as Bezels of Wisdom in 1980.

${ }^{15}$ Born in 1026 and died in 1086, he was a famous Persian Sufi, commentator of the Qur'an, traditionist, polemicist, and spiritual master, known for his oratory, and poetic talents in Arabic, and Persian. 
Tabrizi in 1924 on Akhlaq, Ayatullah Aqa' Mirza Ali Akbar Hakimi Yazdi on philosophy in 1925, Ayatullah Hajj Syaikh Muhammad Rida Najafi Isfahani (1870-1943) on the criticism of Charles Darwin's theory, Ayatullah Sayyid Abu al-Qasim Demkurdi Isfahani (1855-1934), Ayatullah Sayyid Muhsin al-Amin al-Amali (1868-1952) on Hadith and Ayatullah Hajj Syaikh Abbas Qumni (1887-1940). It is obvious that Khumayni's interest in Islamic sciences was quite broad. As had been mentioned he received education not merely in Fiqh, Ushul, Hadith, and the Quranic sciences but also in Akhlaq, Philosophy and Irfan. Additionally, Khumayni was also much interested in Persian literature, Islamic history and general political thought.

It is noted that during the years 1922-1936 Khumayni studied under thirteen teachers in Qumm, and many of them were leading, and highly respected scholars. Some of them were:

1. Ayatullah Aqa' Mirza Muhammad Ali Adib Tehrani (1884-1949), a man of literature (Adib). He studied literature under supervision of Aqa Mirza Kuchak and Aqa Syaikh Buzurg Saviji, leading scholars of Tehran at that time. The writer of some books such as Șarf al-Ṣarf, a text book on Grammar and Hashiyah Bar Mughni al-Labib of Ibn Hisham, he became one of the greatest scholars of Sutuh and literature at the Hawzeh ${ }^{16} \mathrm{He}$ was considered as the first Khumayni's teacher in Qumm. Khumayni studied the Mutawwal (Postulate), a text book on rhetoric from him.

2. Ayatullah Aqa' Mirza Sayyid Ali Yathribi Kashani (1893-1959). He was among the great scholars, and Khumayni studied Fiqh and Uṣul alFiqh under his supervision. Sometime he and Khumayni attended the senior classes of Ayatullah Ha'iri.

3. Ayatullah Hajj Sayyid Muhanmad Taqi Khwansari (1887-1951). Khumayni also studied Fiqih from him. It is noted that Khumayni often

\footnotetext{
${ }^{16}$ Sayyid Ali Shabaz, "The Teachers of Imam Khomeini," transl. quoted from www. imam.khomeini.com
} 
mentioned Khwansari in his lectures or speeches and always recalled him with great respect and admiration as a very distinguished, and an exemplar of socio-political awareness, and resistance against anti-Islamic forces. Khwansari was also acknowledged as one of the leading scholars of Qumm to support Ayatullah Abu al-Qasim Kashani in his political struggle.

All of Khumayni's interest could also be seen from his works. Khumayni has written numerous books on various subjects. Najafiyan catagorizes Khumayni's works into five subjects: Irfan, Akhlaq, and Poetry (sixteen books), Kalamand political thought (six books), Fiqh and Ușūl al-Fiqh (twenty books), Various compilations done by pupils of Khumayni's lectures and Fatawa (seven books), Five collections of Khumayni's speeches, declarations, massages, letters, interviews that have appeared in the last eleven years since the victory of the Islamic revolution of Iran.

\section{Toward an Islamic revolution}

It is undoubtful that modernization implemented during the Shah which was followed by secularization, and westernization of the Iranian society caused public dissatisfaction, marginalization of religion and even criticism from the Ulama who hold firmly Shi'te Islamic tradition. The issue of modernization, and its large implication especially in the muslim countries and the position of Islam have been debated among the scholars, intelligentsias, intellectuals, Ulama, and even the people. Some tend to be more adaptive (adaptationist), and some others to be rejective (rejectionist). The rejectionist muslim in Iran believed that western model of modernization adopted by the Shah's regime should be rejected and changed into a revolutionary Islamic model. There was a need and an attempt to put Islam as an alternative. Haleh Afshar illustrates that after Borujerdi passed away in 1961 there was an attempt "to assert both the 
importance of Islam as a way of life and the need for the religious establishment." ${ }^{17}$ Many Ulama strongly believed that Islam should guide all aspects of life and not be seen as a mere ideology. They argued that Mujtahidun, the high clergy, must not payed much attention only to religious rituals and practices but also to political, and socio-economic activities. Therefore, fundamental changes were advocated both in administrative and financial organization of the religious establishment and its hierarchical structure.

It was Ali Shariati ${ }^{18}$ who popularized the idea of Islam as a way of life and attracted mass support among the youth, and the intelligentsia for the establishment of an Islamic government. He, who had been hailed as JJ.Rousseauand Voltaire of the Iranian revolution, ${ }^{19}$ based his views, and arguments on the sources used by muslims, the Quran, the Hadith or Sunnah, by empasizing Ali's Nahj al Balāghah. He proclaimed:

The true and scientific Shi' ism belongs to those who understand Islam -the religion which was brought to us by Muhammad and those principles which can be deducted from the Quran -on the basis of five principles. I whom am a believer of Imam Ali's Shi' ism understand Islam on the basis of Tawhid (unity of God), Nubuwa (prophethood), Maad (resurrection), Imāmat (belief in twelve Imams) and 'Adl (God's justice). ${ }^{20}$

${ }^{17}$ Haleh Afshar, Iran a Revolution in Turmoil, London: Mac Millan Press Ltd, 1985, 222.

${ }^{18}$ Ali Shariati was born on November 23 ${ }^{\text {rd }}, 1933$, and died on June $18^{\text {th }}, 1977$ when he was 43 years old. Shariati was recognized as an Iranian revolutionary, and sociologist. He was also one of the most influential Iranian intellectual of the $20^{\text {th }}$ century, and has been called the ideologue of the Iranian Islamic revolution. Many academic accounts on Shariati have been published, and some of them are Ervand Abrahamian, Ali Shariati: Ideologue of the Iranian Revolution, in Edmund Burkeand Ira Lapidus (ed), Islam, Politics, and Social Movements, Los Angeles: University of California Press, 1982; Ali Rahmena, An Islamic Utopian, a Political Biography of Ali Shariati, London: I.B. Tauris, 2000.

${ }^{19}$ Ali Rahmena and Farhad Nomani, The Secular Miracle: Religion, Politics, and Economic Policy in Iran, London: Zed Books Ltd, 1940, 5.

${ }^{20}$ Ali Rahmena and Farhad Nomani, The Secular Miracle..., 52. 
Shariati exploited Shi' ism, and the teaching of the first Imam Ali as the basis for his fundamental arguments for changing society and strongly critisizing the false of western values. ${ }^{21} \mathrm{He}$ denounced Marxism as tyrannical, and capitalism as exploitative, and campassion tought by Ali. He strongly suggested that the prosperity, welfare and cultural development of Iran were only possible through an anti-imperialist movement, and mass support was absolutely needed. Realizing the fact that Iranian ruler allied with and even subordinated to the imperialist, anti-imperialist struggle had to become an anti-despotic movement. ${ }^{22}$

Additionally, the modernization, and westernization adopted by the despotic government according to Ali Shariati were essentially reflected in the implementation of a dependent capitalism, along with the prevalence of an imported vulgarized western culture, values, and morals. Democracy was also not implemented by the Shah's regime. Meaningly, the autocratic character of the regime steered to the conclusion that a tyrannical political system was an integral part of westernization. In another words westernization was a symbol of the negative, undesirable, and should be totally rejected because it caused political repression, economic exploitation, cultural alienation, and moral corruption.

Interestingly, university students, intelligentsias, and urban middle class society supported Shariati's notion to oppose the Shah's regime and popularized the radical and revolutionary Islam. They had accepted both fundamentalist Islamic ideology transmitted by Ulama and clerical leadership as well. As Malekzadeh points out there were two factors seem to accounts. First, they were aware of the influence of the Shi' ite hierocracy on the masses, and sought to use it against the Pahlevi regime. Second, they were impressed by the oppositional role of the Ulama to the state

${ }^{21}$ For his specific work on the false of western values, and fallacies read Ali Shariati, transl, R. Campbell, Berkeley: Mizan Press, 1980.

${ }^{22}$ Ali Rahmena and Farhad Nomani, The Secular Miracle..., 53. 
in recent Iranian history and full of unrequited admiration for them. ${ }^{23}$ Their support to the oppositional idea was partly expressed by flourishing religious activities. For publication, for instance, they involved in publishing religious periodicals. It is noted that religious periodicals gained progressively wider circulation, and religious books became more popular. A survey conducted in 1976 found that there were forty eight publishers of religious books in Tehran alone, of whom twenty six had begun their activities during 1965 to 1975 decade. A large number of Islamic association also mushroomed and had far reaching consequence for the politization of the Islamic resurgence, and the roles of intelligentsias were very fundamental.

It is obvious that Khumayni did not pay much attention to the intelligentsia's political criticism, and opposition to the Shah's regime. He remained emphasizing to preach, confine to the lower ranks of the hiepocracy, and encourage a large number of preachers to spread his message among the common people in Iran, and among the Iranian pilgrims abroad. Reportadly, in the mid 1970s Khumayni trained 500 Mujtahids, and 12.000 students attended his lectures in the years immediately preceding his exile in 1964. Most of them then became leading militant Ulama who posted in the highest position of power since the revolution in Iran.

${ }^{23}$ As cited by Said Arjomand, The Turban for the Crown: the Islamic Revolution in Iran, New York, Oxford: Oxford University Press, 1989, 91. 


\section{Kashf al-Asrār: the first Khumayni's political theory}

Khumayni's activities in Qumm coincided with the rise to power of Reza Khan, the father of Reza Shah, and founder of the Pahlevi dynasti. He established a strong central government, and westernized Iran.He also secularized and codified the laws, adopted European-style law codes, and established a system of secular court that fundamentaly reduced and marginalized the functions, and rules of the Ulama. Then, the government required judges to hold a law degree from the newly established Tehran University preventing the graduates of the religious seminaries from becoming judges. ${ }^{24}$ Shah, moreover, endeavored to control, and challenged the Ulama even on their home ground of religious education by establishing centre of Islamic studies at Teheran University. The government interfered in both the certification of seminary students, and graduates and the curriculum of the religious schools in an effort to modernize them.

The modernization, and secularization policy of the government caused negative reaction from the Ulama. They were dissatisfied, and disappointed with these developments manifested it self in passive resistance that occasionally broke out into active opposition. Amuzegar underlines that the modernization imposed by the Shah was very outrageous ${ }^{25}$ which caused opposition to the Shah. In 1927, for example, Hajj Aqa' Nurullah, a religious leader in Isfahan, led a mass protest march from Isfahan to the shrine at Qumm. Then in 1828 Ayatullah Muhammad Taqi Bafqi strongly protested against the unmannerly, and unlawful presence of women of Riza Sha's family without Hijab inside the shrine of Hadrat Ma'sumah at Qumm during the month of Ramadhan. Najafiyan quoted

\footnotetext{
${ }^{24}$ Shaul Bakhash, The Reign of Ayatullahs Iran, and the Islamic Revolution, New York: Basic Books, Inc. Publisher, 1984, 21.

${ }^{25}$ Jamahir Amuzegar, The Dynamics of the Iranian Revolution, New York: State University of New York Press, 1991, 38.
} 
the questions of Ayatullah Muhammad Taqi Bafqi to the royal visitors: "Who are you people? If you are adherent of Islam, then what are you doing here in this holy place? If you are muslims, then why are you sitting with uncovered heads and faces in the chamber of the shrine in the presence of several thousand people.?"26 As a consequence, Ayatullah Muhammad Taqi Bafqi was dragged out of the shrine and beaten by Reza Shah. Repeatedly, clerical leaders who criticized and opposed against the Shah were also imprisoned and exiled.

The frequent opposition of the Ulama which was then supported by students, intelligantsias, and urban middle class society pushed Khumayni to move giving speeches, declarations, and criticized the regime. His explaination on his position in the context of politics in Iran was illustrated in his work Kashf al-Asrär (the unveiling of secrets). ${ }^{27}$ In this book, which was written shortly after Reza Shah's abdication in 1941, Khumayni gave vent to his feelings about the Shah. This book was an early exposition of Khumayni's ideas on the relationship between religion, and state.

Kashf al-Asrär consist of six part. The first part is refutation of Wahabi's doctrines, the second part is about Imamate, the third part deals with the authority, and legal power of Mujtahidun, the fourth, and fifth part

\footnotetext{
${ }^{26}$ Sa'id Najafiyan, "Imam Khumayni..., 125.

27 This book was written by Khumayni in 1943. The same tittle of the book, Kashf alAsrär, was actually also written by Ruzbihan al-Baqli (1128-1209), the most significant mystics of twelfth-century Iran. It was the visionary autobiography of al-Baqli written in Arabic describing his life journey primarily as comprised of his mystical visions. An important account about this Kashf al-Asrär is written by Firoozeh Papan-Martin in collaboration with Michael Fishbein in The Unveiling of Secrets Kashf al-Asrär, The Visionary Autobiography of Ruzbihan al-Baqli 1128-1209 A.D, Brill: 2005. Another Kashf al-Asrär was written by Rashid al-Din Maybudi, a major twelfth-century scholar of Maybud, Iran. This book is acknowledged as one of the earliest and longest commentaries on the Quran (Tafsir al-Qur'an) from the sufist perspective written in Persian then translated by William C. Chittick in 2014. Rashid al-Din Maybudi, The Unveiling of the Mysteries and the Provision of the Pious Kashf al-Asrar wa Uddat al-Abrār, transl Amman, Jordan: Royal Aal al-Bayt Institute for Islamic Thought, 2015.
} 
the book discuss issues related to Islamic government. Then, the sixth part answers criticism against the notion of the perpetual validity of Islamic laws and discusses the causes behind the general decline of interest in religion. ${ }^{28}$ Bakhash comments some Khumayni's ideas:

Khumayni treated Reza Shah as a usurper, the parliaments of the period as lacking in legitimacy, the laws they had approved as harmful, the ministries as corrupt, the police cruel, and officials as lacking in concern for the poor and the downtrodden. He attributed this condition in large part to Reza Shah's deliberate policy of ignoring Islamic precepts, and undermining the religious community. ${ }^{29}$

This book basically political. Khumayni's targets were Reza Shah's dictatorial government, and secularism. He, like Dilip Hiro points out, argued that since the laws enforced during Reza Shah's regime had not been vetted by a committee of Mujtahid, as the constitution specified, they must be repealed. ${ }^{30}$ He quoted what Khumayni said: "we say that the government must be run in accordance with God's law for the welfare of the country, and the people demand it." ${ }^{11}$ About the enforcement of the law Khumayni underlined that it was not possible to implement, and impose the law without supervision of the religious leaders. Factually this principle has been approved, and ratified in the constitution and no any conflicts with public order, the stability of the government and the interest of the country. It is clear that Khumayni actually tended to be constitutionalist in a sense that, according to Khumanyni, the government and all policies should be based on the constitution defined by parliament, not defined by the ruler. Khumayni believed that the regime was strongly

${ }^{28}$ Sa'id Najafiyan, "Imam Khumayni”..., 145.

${ }^{29}$ Sa'id Najafiyan, "Imam Khumayni”..., 145.

${ }^{30}$ Dilip Hiro, Iran Under the Ayatullahs, London and New York: Routledge \& Kegan Paul, 1987, 50

${ }^{31}$ Dilip Hiro, Iran Under the Ayatullahs..., 50. 
influenced by the imperialism to marginalizeand eliminate Islam. The hostility to Islam was undoubtful. He clearly underlined:

The hostility of Pahlevi regime to Islam was not merely the ideosyncratic desire of a single dictator but rather part of comprehensive strategy for the elimination of Islam as a social, and political force throughout the Islamic world, and as such has been conceived by the major centers of imperialism, and entrusted to the various local agents of imperialism.... all the orders issued by the dictatorial regime of the bandit Reza Khan have no value at all. The law passed by his parliament must be scrapped, and burned. All the ideotic words that have proceeded from the brain of that illiterate soldier are rotten, and it is only the law of God that will remain, and resist the ravages of time. ${ }^{32}$

Despite the political criticism covered in Kashf al-Asrär some scholars argue that it is difficult to find Khumayni's notion about Islamic government or the government in the hands of Faqih. There is no any evidence to say that Khumayni talked about Islamic government in his Kashf al-Asrār. It is Cheryl Bernard Khalilzad who support this opinion by quoting Khumayni's statement: "we dont say that government must be in the hands of the Faqih. Rather we say that the government must be run in accordance with God's law," ${ }^{33}$ and accordingly, Khumayni supported the principle of secular rule as essential to keep order gaining that "a bad government is better than no government." 34

Some speculate that this basic notion of Khumayni on government was strongly influenced by Muhammad Hasan Borujerdi, the Marjai Taqlid. Borujerdi prohibited the Ulama from joining parties, and participating politics. This could be meant that no place for Ulama or Faqih

\footnotetext{
${ }^{32}$ Hamid Algar, The Roots of the Islamic Revolution, Canada: The Open Press, 1983, 44-45.

${ }^{33}$ Cheryl Bernard and Zalman Khalilzad, The Government of God Iran's Islamic Republic, New York, Columbia University Press, 1984, 37.

${ }^{34}$ Cheryl Bernard and Zalman Khalilzad, The Government of God..., 37.
} 
involving, and influencing the power from within. This low profile of political performance of the Ulama suggested by Borujerdi was probably based on the fact that regime became more powerful on one hand, and the Ulama's position became weak on another. Akhavi clearly illustrates the position of the Ulama in Majelis. In in the 6th Majelis (1926) $40 \%$ of the members were from the religious establishment. However, by 1930 the percentage was reduced significantly to $30 \%$, and by the 11 th there was no single well known Ulama among the deputies. ${ }^{35}$ So, as far as Borujerdi's suggestion is concerned, Khumayni seemingly did not tend to openly denunciate the regime particularly in the period between the downfall of Reza Khan in 1941 and the overthrow of Mossadeq in 1953. It should be said that "throughout this period he sought to induce a measure of political realism and commitment in Ayatullah Borujerdi."36

\section{Wilāyat al-Fāqih}

Khumayni began to think more seriously about an Islamic government as an alternative to the dictatorial regime in the late 1960s. This book represents a concrete plan for an Islamic ideological based-government. It consists of Khumayni's lectures on Fiqh that delivered at the mosque of Shaikh Anshari when he was in Najf. Actually the entire series of these lectures have been compiled in Kitäb al-Bayā, and his particular account on Wilayat was only a small part of it. This book consists of, at least, twelve of his lectures on the traditional topics of the scope of the authority of an Islamic legist or Fäqih.

The following is an attempt to discuss on both Wali and Muwalla 'Alayh, and inter-relating concept with Wilàyat, and illustrate some Khu-

35 S. Akhavi, Religion, and Politics in Contemporary Iran, Albany, State University of New York Press, 1980, 59.

${ }^{36}$ Hamid Algar, The Roots of the Islamic Revolution.., 45. 
mayni's notion covered in Wilayat. ${ }^{37}$

1. Wali. The term of Wali refers to qualified Fäqih that literally means someone who understands well. Fäqih does not refers to any knowledgeable man or expert in general science but merely to a particular class of experts who specialize in the science of Fiqh. Fäqih is one who specialize and expert in Islamic jurisprudence or Fiqh. He is also a Mujtahid who qualified to give Fatwa with regard to the ordinances of Islam (Shari'ah Islamiyah). Then, since a Faqih is an individual who possesses the ability to derive all of the general rules, and legal commandements of Islam from the original sources, he should have sufficient training in the preliminaries requisite for deduction and should be able to derive and deduce any of the Islamic Syariah by investigating, and examining the source as well. Mishkini describes that there are, at least, six prerequisites needed to gain the status of Faqih: Arabic language, grammar, and Syntax, Ușul a-Fiqh, 'Ilm al-Hadith, 'Ilm al-Rijal, and full knowledge of the relevant Quranic verses.

2. Muwalla Alayh. Muwalla means something or someone needs a guardian, and protection because he is not capable to manage himself. Muwalla Alayh refers to both something or assets and peoples. There are five kinds of assets which need protection from a Wali. (a) Private property (b) Quasi-public property like Mawqufat. The protection of these two properties could be either from particular trustees or Islamic judge (c) Government property like Khums, Anfal (d) National property such as conquered land, and Zakat. The guardianship of these two properties is under the qualified Fäqih (e) Public property which does not belong to any particular individual, and needs guardianship, like

37 The illustration of these concept given here is basically based on Ayatullah Ali Mishkini's article entitled, "Wilayat al-Faqih: Its Meaning, and Scope," Tawhid, Vol. II, No 4 (July-September 1985). 
mosques, shrines, holy sport, streets. Moreover, the person who are Muwalla 'Alayh can be divided into five categories: minnors, orphans, insane, slaves and society as a whole. These all Muwalla 'Alayh need protection from Wali, and could not be alone. Oherwise, it could cause chaos, and social instability.

Some questions then could be adressed how to determine precisely that society is either capable or incapable to manage their own duties or affairs, in what aspects of social life Wilayat does apply? Mishkini points out that Islamic teaching have provided clarification about that. He mentions: "an examination of the rule of the prophet, and Imam Ali clearly shows the nature, and limits of Wilayat, the obligations, and rights of the Wali, and Imam, and the cases in which the Wali is authorized over the people's property of their persons," 38 and as far as the scope of Wilāyat is concerned Mishkini argues that there are three sources of argument, i.e. the judgement of reason, the practice of the wise (Sirat al-'Uqala'), and the textual or cannonical proofs (Adillah Naqliyah).

Finally, it is no doubt that if people being left without having any protection or guardian from Wali there will be corruption, injustice, discord, violence, chaos, destruction of humanity, and property. Khumayni strongly suggested that the only way is to save the society, and nation through an effective authority which control over the people. The roles of Ulama or Mujtahid could not be ignored to establish a just state or government. The westernized, tyrannical, dictatorial, and secular government as implemented by Shah could not establish a just, and peaceful society. Consequently, there should be a revolutionary efforts or Jihad to change the regime into a new system of government based on Shi' ite Islamic ideology, and the roles of Mujtahids were absolutely fundamental. The idea of an Islamic government according to Khumayni was also paramount.

\footnotetext{
${ }^{38}$ Ayatullah Ali Mishkini "Wilayat al-Faqih”..., 48.
} 


\section{Fäqih}

In his Wilāyat Khumayni seemingly generalized the early Ușuli $>$ arguments which were designed to establish the legal, and religious authority of the Shi' ite Mujtahid to eliminate the duality of religious and temporal authority. By rejecting the separation of religion, and politics Khumayni argued that in the absence of divinely inspired Imam sovereignty devolves upon qualified jurist of the Shi' ite religious leaders. This is actually the basic political problem in the Shi'te tradition. Ramy Nina comments that the main theoretical problem for Khumayni was Shi'ite political theory, the theory of Imamate. This ortodox Shi' ite doctrine states that the Imams were rightful, and legitimate authorities after the death of the Prophet. The Imam, in Shi' ism, derives his authority not from his temporal existence, practice, and from the community's acceptance of leadership but from his inner, divinely ordained quality. The light of God is within him and it is this that gives him his worldly power and authority. In the practical level, like Najafiyan mentions,"the Fäqih has authority over the ruler." ${ }^{39}$ If the ruler is Muslim he consequently must submit to the Fäqih asking him about the laws, and ordinances of Islam in order to implement them.

Another thing that was emphasized by Khumayni is that the Fuqaha are trustees of the Prophet. It means that all of the task entrusted to the Prophet must also be fulfiled by the just Fuqoha. He said it is merely the just Fuqaha who may correctly implement the ordinances of Islam and firmly establish its constitutions executing the penal provisions of Islamic law and preserving the boundaries, and territorial integrity of the Islamic homeland. If Fäqih has as his aim the accumulation of wordly wealth he is no longer justand can not be trustee of the Prophet, and executor of the ordinance of Islam.

\footnotetext{
${ }^{39}$ Said Najafiyan, "Imam”..., 107.
} 


\section{The necessity of the Islamic government}

To strengthen the idea on the necessity of the Islamic government Khumayni illustrated a part of the nature of the Quran and Hadith. He said:

The nature of Quranic verses concerned with the affairs of society to those concerned with ritual worship is greater than a hundred to one. Of the approximately fifty sections of the corpus of Hadith four sections relate to matters of ritual worship, and the duties of man toward his Creator and Sustainer. A few more are concerned with questions of ethics, and all the rest are concerned with social, economic, legal, and political questions. ${ }^{40}$

Khumayni's statement means that the idea to establish an Islamic government is theologically justified. His radical views on Islam was an integral part of his attempt to reject the existing monarchy of Shah which was strongly subordinated by the foreign power. He underlined that Islam proclaimes monarchy, and hereditary succession is wrong and invalid. He argued; "when Islam appeared in Iran, the Byzantine empire, Egypt and Yemen, the entire institution of monarchy was abolished." ${ }^{41}$ In his letter sent to Byzantine emperor Heraclitus, and the Shahanshah of Iran the Prophet Muhammad called upon them to abandon the monarchical, and imperial form of government, to cease compelling the servants of God, who has no partner, and is the true monarch. Khumayni believed that Islam does not recognize monarchy, and hereditary succession; they have no place in Islam, and should be changed over by a system of Republic of Islamic government. The system is theologically believed in accordance with the Islamic tenets, and compatible with the need of justice, and prosperity.

\footnotetext{
40 Said Najafiyan, "Imam"..., 97.

${ }^{41}$ Said Najafiyan, "Imam”..., 98.
} 
There are, at least, three other reasons supporting the idea of the necessity of the Islamic government:

1. Sunnah. The Sunnah, and the path of the Prophet obviously constitute of the necessity for establishing government. It is undoubtful that historically the Prophet himself established a government, and designated a ruler to succeed him in accordance with the divine command. If God through his Prophet, designated a man to rule over Muslim society after him, this is an historical precedent that government should be established after the death of the Prophet. This also clearly indicate that enactment of the law, establishment of executive and administrative organs are also necessary after the death of the Prophet. Otherwise, chaos, and anarchy will prevail, and social, intellectual and moral corruption will arise.

2. The nature of Islamic law. The nature, and character of Islamic law, and divine ordinance of the Syariah indicate that laws are laid down for the purpose of creating a state, and administering political, aconomic, and cultural affairs of the society. Islamic law should be properly enforced for the sake of social stability and peace, humanity, justice, and prosperity. Islam provides law, and instructions for all of the people need aiming to produce integrated, and virtous human beings. In other words law, and instructions is absolutely needed to create conditions conducive to the production of morally upright, and various human beings.

3. The unity of the Islamic Ummah. Khumayni acknowledged that in the past Muslim in Iran were not capable to establish a proper government, and overthrow treacherous, and corrupt rulers which resulted from the absence of unity and unanimity as well. Many of them even tended to be apathetic, and reluctant to discuss the necessary of Islamic government. They did not have enough capability to resolve firmly 
their problems. Khumayni listed some fundamental problems faced by Muslim: the sovereignty of Islam in society have declined; the nations of Islam have been weak and disintegrated; the laws of Islam have been subjected to change, and modify; the imperialists have propogated foreign laws, and culture among the Muslims; Muslims have been infatuated with the West. Khumayni also clearly stated that Iranian peoples were lack of a leader, a guardian, and a strong institution of leadership. In order to solve the problems, strengthen the unity, and liberate the Islamic homeland from occupation, and penetration by the imperialists Khumayni strongly recommended to establish a government based on Islamic ideology, and overthrow the oppressive government. An Islamic government of justice is absolutely needed to serve the people. He realized that the formation of a such government will serve to preserve the discipline unity of the Muslim.

Finally, following the reasons above it is obvious that according to Khumayni the establishment of Islamic government is necessary. Consequently, any non-Islamic government should be totally rejected. The proofs are clear: the existence of a non-Islamic political order necesserily results in the non-implementation of the Islamic political order; All non-Islamic system of government are the system of Kufr. According to Khumayni "the duties of Muslim are firstly to remove them from Kufr and destroy them. Secondly, to create a favourable social environment that is in total contradiction with that produced by the rule of T\}a $>$ ghu>t, and illegitimate power." 42

\section{Conclusion}

Khumayni, whose family background was religious, grew as an educated person. His early education was under his family then he experienced

\footnotetext{
${ }^{42}$ Said Najafiyan, "Imam”..., 102.
} 
widely his studies in variety of subjects from a number of great scholars in some places. From his earliest period of education Khumayni begun show his intellectual capability and talent. His intellectual thought, and religiousity was much influenced by Ayatullah Hajj Syaikh Abd al-Karim Hairi Yazdi. Khumayni was considerably an heir to the tradition established by the very influential Shi' ite figures of the 19th century Iran.

Having been impressed, and inluenced by Ha'iri's notion especially on Fiqh, and Ushul Khumayni wrote twenty books on the field. Kashf al-Asrār, and Wilayat al-Fäqih were the most popular, and influential works on Fiqh written in different time, manner, and perspective. Despite the distinction between the two Khumayni responded to the existing dictatorial government, and proposed his idea for the solution. In Wilàyat al-Fäqih Khumayni radically exposed Islam as the sole ideology, system of life, and an Islamic government in Iran as well.

\section{Bibliography}

Abrahamian, Ervand, "Ali Shariati: Ideologue of the Iranian Revolution", in Edmund Burke and Ira Lapidus (eds.). Islam, Politics, and Social Movements. Los Angeles: University of California Press, 1982.

Afshar, Haleh. Iran a Revolution in Turmoil. London: Mac Millan Press Ltd, 1985.

Akhavi, S. Religion, and Politics in Contemporary Iran. Albany: State University of New York Press, 1980.

Algar, Hamid. The Roots of the Islamic Revolution. Canada: The Open Press, 1983.

Amuzegar, Jamahir. The Dynamics of the Iranian Revolution. New York: State University of New York Press, 1991.

Arjomand, Said. The Turban for the Crown: the Islamic Revolution in Iran. New York, Oxford: Oxford University Press, 1989.

Bakhash, Shaul. The Reign of Ayatullahs Iran, and the Islamic Revolution. New York: Basic Books, Inc. Publisher, 1984. 
Bernard, Cheryl and Zalman Khalilzad. The Government of God Iran's Islamic Republic. New York: Columbia University Press, 1984.

Hiro, Dilip. Iran Under the Ayatullahs. London and New York: Routledge \& Kegan Paul, 1987.

Khomeini. Islam and Revolution. trans. Hamid Algar. Berkeley: Mizan Press, 1981

Mavani, Hamid,"Ayatullah Khomeini's Concept of Government (Wilāyat al-Fäqih) and the Classical Shi'i Doctrine of Imamate", Middle Eastern Studies, vol. 47, no. 5 (October, 2011): 807-824.

Mavani, Hamid, "Khomeini's Concept of Governance of the Jurisconsult (Wilāat al-Fäqih) Revisited: The Aftermath of Iran's 2009 Presidential Election”, The Middle East Journal, vol.67, No. 2 (Spring, 2013): 207-228

Mishkini, Ayatullah Ali, "Wilāyat al-Fāqih: Its Meaning, and Scope," Tawhid, vol. III, no. 1 (July-September 1985): 29-65.

Najafiyan, Sa'id, "Imam Khumayni: Life and Works," al-Tawhid, vol. VII, no. 4 (May-June 1990): 117-135.

Najafiyan, Sa'id, "Imam Khumayni: Life and Works." Al-Tauhid. Vol .VIII no 2 (November 1990-January 1991): 137-156.

Rahmena, Ali. An Islamic Utopian, a Political Biography of Ali Shariati. London: I.B. Tauris, 2000.

Rahmena, Ali and Farhad Nomani. The Secular Miracle: Religion, Politics, and Economic Policy in Iran. London: Zed Books Ltd, 1940.

Shabaz, Sayyid Ali. "The Teachers of Imam Khomeini," transl. quoted from www.imam.khomeini.com

Shevlin, Neil, "Velayat-i Faqih in The Constitution of Iran: The Implementation of Theocracy", Journal of Constitutional Law, vol.1, mo. 2 (Fall, 1998): 358-382.

Wise, Krysta, "Islamic Revolution of 1979: The Downfall of AmericanIranian Relations”, Legacy, vol.11, no. 1 (2011): 1-17. 